Article

\title{
Design, Synthesis, Crystal Structure, and Fungicidal Activity of Two Fenclorim Derivatives
}

\author{
Ke-Jie Xiong and Feng-Pei Du * \\ Department of Applied Chemistry, College of Science, China Agricultural University, Beijing 100193, China; \\ kejieailan@163.com \\ * Correspondence: dufp@cau.edu.cn; Tel.: +86-10-62732507
}

Received: 21 June 2020; Accepted: 4 July 2020; Published: 7 July 2020

\begin{abstract}
Two fenclorim derivatives (compounds 6 and 7) were synthesized by linking active sub-structures using fenclorim as the lead compound. The chemical structures of the two compounds were confirmed by NMR spectroscopy, high resolution mass spectrometry, and X-ray diffraction analysis. Their fungicidal activity against six plant fungal strains was tested. Compounds 6 and 7 both crystallized in the monoclinic system, with a P2 $1 / \mathrm{c}$ space group $(\mathrm{a}=8.4842(6) \AA, \mathrm{b}=24.457(2) \AA$, $\left.\mathrm{c}=8.9940(6) \AA, \mathrm{V}=1855.0(2) \AA^{3}, \mathrm{Z}=4\right)$ and Cc space group $(\mathrm{a}=10.2347(7) \AA, \mathrm{b}=18.3224(10) \AA$, $\mathrm{c}=7.2447(4) \AA, \mathrm{V}=1357.50(14) \AA^{3}, \mathrm{Z}=4$ ), respectively. The crystal structure of compound 6 was stabilized by $\mathrm{C}-\mathrm{H} \cdots \mathrm{N}$ and $\mathrm{C}-\mathrm{H} \cdots \mathrm{O}$ hydrogen bonding interactions and $\mathrm{N}-\mathrm{H} \cdots \mathrm{N}$ hydrogen bonds linked the neighboring molecules of compound 7 to form a three-dimensional framework. Compound 6 displayed the most excellent activity, which is much better than that of pyrimethanil against Botrytis cinerea in vivo. Additionally, compound 6 exhibited greater in vitro activity against Pseudoperonospora cubensis compared to that of pyrimethanil. Moreover, compound 7 exhibited strong fungicidal activity against Erysiphe cichoracearum at $50 \mathrm{mg} / \mathrm{L}$ in vitro, while pyrimethanil did not. Compounds 6 and 7 could be used as new pyrimidine fungicides in the future.
\end{abstract}

Keywords: synthesis; crystal structure; fenclorim; antifungal activity; pyrimidine

\section{Introduction}

Plant diseases caused by fungi can significantly affect the growth and development of crops such as potato, soybean, and rice, and reduce the yield ( $20 \%$ perennial yield losses and $10 \%$ postharvest losses) of crop plants globally [1-4]. Meanwhile, fungal plant diseases also cause fresh fruit yield loss due to the shortening of storage times and secretion of fungal toxins that can damage human health $[5,6]$. Chemically synthesized fungicides are a major tool that producers use to protect against plant diseases. However, long-term and unreasonable application of fungicides has led to the emergence of resistance [7-11]. Hence, novel and efficient fungicides are necessary to solve problems arising from current fungicide resistance.

Fenclorim (4,6-dichloro-2-phenyl-pyrimidine, Figure 1a) is a commercial herbicide safener, which could alleviate the injury caused by chloroacetanilide herbicides, especially pretilachlor, without affecting their herbicide activity [12,13]. Zheng et al. [12] showed that fenclorim exhibited excellent in vivo fungicidal activity against Sclerotinia sclerotiorum, Fusarium oxysporum, Fusarium graminearum, and Thanatephorus cucumeris, and could be used as a lead compound to design novel pyrimidine-type fungicides. A fenclorim derivative, named $\mathrm{N}$-(4,6-dichloropyrimidine-2-yl) benzamide, was synthesized by inserting an amide group between the phenyl ring and the pyrimidine ring in fenclorim to study the activity relationship (SAR) against fenclorim. This derivative displayed greater fungicidal activity than that of lead fenclorim and the positive control of pyrimethanil against Sclerotinia sclerotiorum and Fusarium oxysporum, with in vivo $\mathrm{IC}_{50}$ values of 1.23 and $9.97 \mathrm{mg} / \mathrm{L}$, 
respectively. These results indicate that the modification of fenclorim can produce highly active fungicidal compounds and that fenclorim provides broad potential as a lead compound for screening fungicides.<smiles>Clc1cc(Cl)nc(-c2ccccc2)n1</smiles>

(a)<smiles>CO/C=C(/C(=O)OC)c1ccccc1Oc1cc(Cl)nc(-c2ccccc2)n1</smiles>

(b)<smiles>Cc1cc(C)nc(Nc2ccccc2)n1</smiles>

(c)

Figure 1. Chemical structure of fenclorim (a), azoxystrobin (b), and pyrimethanil (c).

Azoxystrobin (Figure 1b) and pyrimethanil (Figure 1c) are commercial pyrimidine fungicides. Azoxystrobin, named methyl (E)-2-\{[6-(2-cyanophenoxy)-4-pyrimidinyl]oxy\}-alpha-(methoxy methylene)benzeneacetate, belongs to the strobilurin fungicides, and was commercialized in 1996. Azoxystrobin stably held $23-25 \%$ of the fungicide market share until 2016. Azoxystrobin is a broad-spectrum fungicide and that displays strong activity against plant fungi such as ascomycetes, deuteromycetes, and oomycetes in crop plants, vegetables, and fruits [14]. Azoxystrobin causes the mitochondrial respiration of pathogenic fungi to be hindered, by binding to the $\mathrm{Q}_{0}$ site of cytochrome bc1 enzyme complex to block electron transfer and freeze adenosine triphosphate (ATP) production [15]. Pyrimethanil, named 4,6-dimethyl- $N$-phenylpyrimidin-2-amine, was commercialized in 1991 and controlled plant fungi such as pear scab (Venturia pirina) and gray mold (Botrytis cinerea) in agricultural product [16]. It acts as an athogenesis inhibitor to inhibit the secretion of cell wall degrading enzymes in plant fungi [17].

The linking of active sub-structures to compounds is a common method for identifying novel pesticides [18-20]. Here, in order to find new fungicide candidates with high efficiency, two fenclorim derivatives (compound 6 and 7 ) were synthesized via the linking of active sub-structures. This was achieved by combining the (Z)-methyl 2-iodo-3-methoxyacrylate group substituted phenoxy group (red) in azoxystrobin and the aminophenyl group (pink) in pyrimethanil (Scheme 1). The chemical structures of compounds 6 and 7 were confirmed by NMR spectroscopy, high-resolution mass spectrometry (HRMS) and X-ray diffraction analysis. Their fungicidal activity against Botrytis cinerea (B. cinerea), Pseudoperonospora cubensis (P. cubensis), Erysiphe cichoracearum (E. cichoracearum), Blumeria graminis (B. graminis), Rhizoctonia solani (R. solani), and Puccinia polysora (P. polysora) were evaluated. These results provide useful guidance for designing novel fungicides using fenclorim as a lead compound.

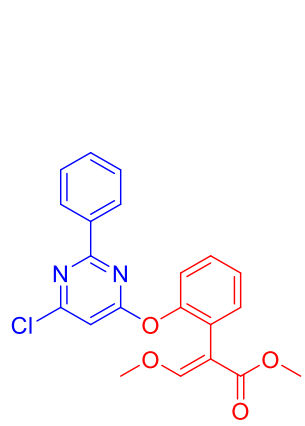

6
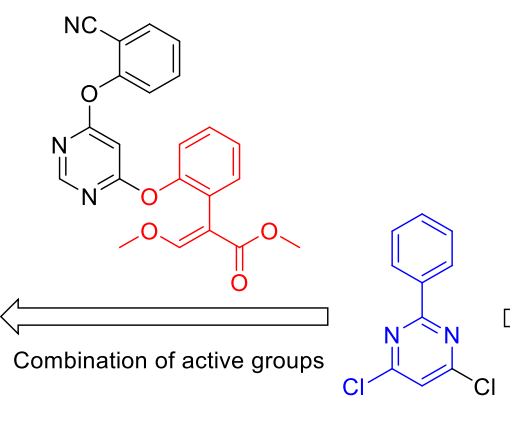

fenclorim

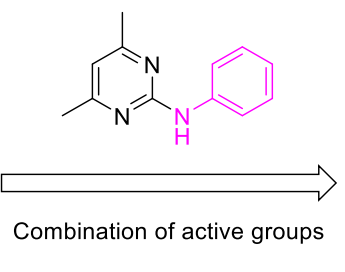

Cl

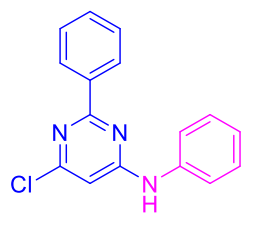

7

Scheme 1. Design strategies for compounds 6 and 7. 


\section{Materials and Methods}

\subsection{Chemicals}

All chemicals used in this research, including reagents and starting materials, were obtained from the Jilin Chinese Academy of Sciences, Yanshen Technology Co., Ltd., Jilin, China. ${ }^{1} \mathrm{H}$ and ${ }^{13} \mathrm{C}$ NMR spectra were recorded using a Bruker Avance-300 spectrometer (Bruker AXS, Karlsruhe, BW, Germany) operating at $300 \mathrm{MHz}\left({ }^{1} \mathrm{H}\right)$ and $75 \mathrm{MHz}\left({ }^{13} \mathrm{C}\right)$, respectively, with chemical shifts reported in ppm $(\delta)$. Deuterated chloroform $\left(\mathrm{CDCl}_{3}\right)$ was used as the solvent and tetramethylsilane (TMS) was used as the internal standard. HRMS analysis data was obtained on an FTICR-MS Varian 7.0 T FTICR-MS instrument (Varian IonSpec, Lake Forest, CA, USA). Melting points were measured using a Hanon MP100 automatic melting point instrument (Jinan Hanon Instruments Co., Ltd., Jinan, Shandong, China) using an open capillary tube. X-ray crystal structures of compounds 6 and 7 were measured using a Bruker SMART APEX II X-ray single-crystal diffractometer (Bruker AXS, Karlsruhe, BW, Germany). Reagents obtained from commercial sources were used without further purification.

\subsection{Synthetic Procedure}

Target compounds 6 and 7 were synthesized based on methods reported in the literature [21-23]. The synthetic routes of target compounds 6 and 7 are described in Scheme 2; Scheme 3.

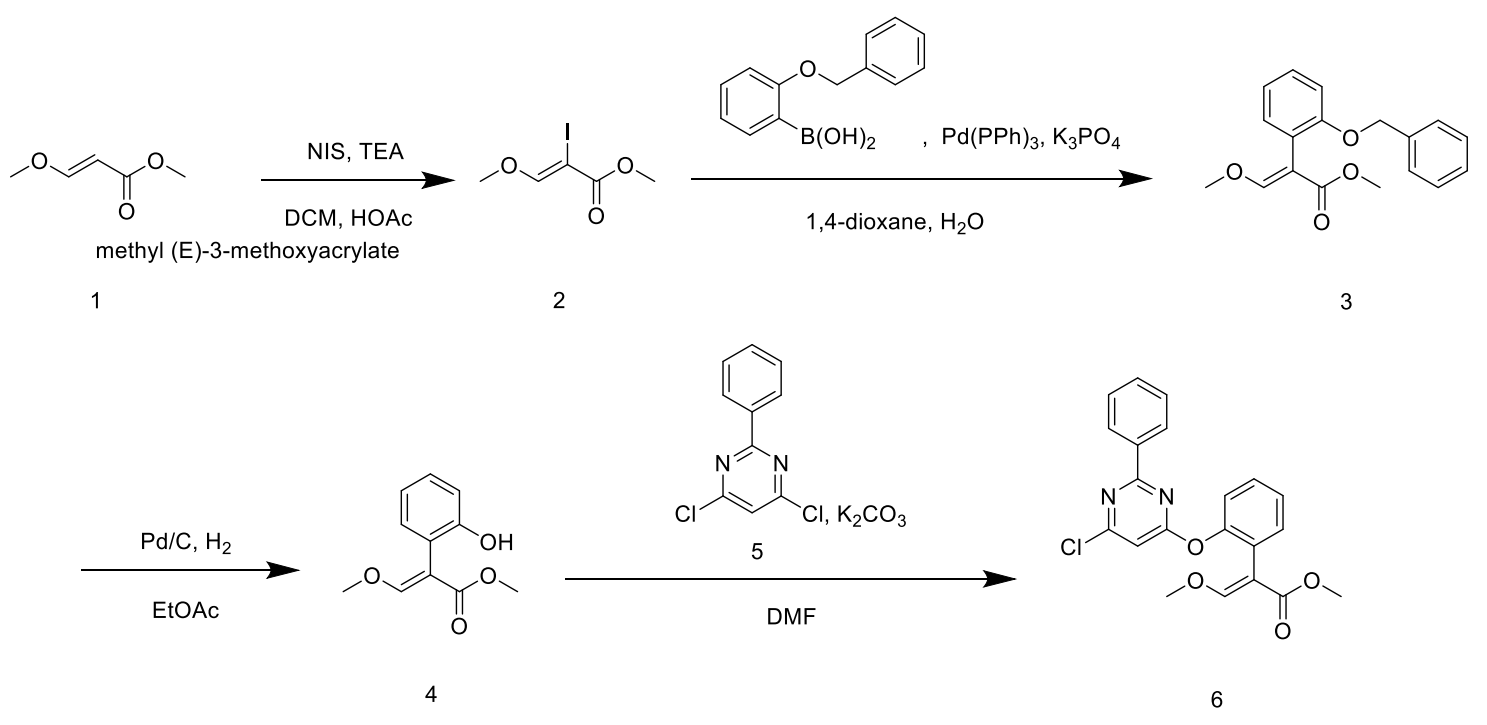

Scheme 2. The synthetic route of target compound 6 .<smiles>Clc1cc(Cl)nc(-c2ccccc2)n1</smiles>

5

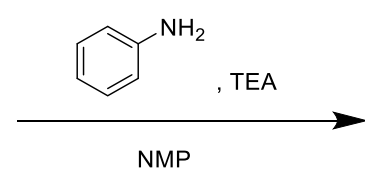

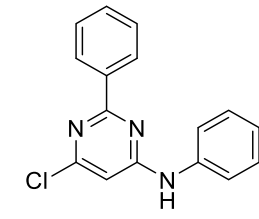

7

Scheme 3. The synthetic route of target compound 7.

\subsubsection{Synthesis of (Z)-methyl 2-iodo-3-methoxyacrylate (2)}

A mixture of 1 (1.00 g, $8.61 \mathrm{mmol}), \mathrm{N}$-iodosuccinimide (NIS, $2.32 \mathrm{~g}, 10.33 \mathrm{mmol})$, glacial acetic acid $(0.98 \mathrm{~mL}, 17.22 \mathrm{mmol})$, and dichloromethane $(15 \mathrm{~mL})$ was stirred at $20{ }^{\circ} \mathrm{C}$ for $24 \mathrm{~h}$. Afterwards, triethylamine (TEA, $4.2 \mathrm{~mL}, 30 \mathrm{mmol}$ ) was added dropwise. The reaction mixture was then stirred at 
$20{ }^{\circ} \mathrm{C}$ for another $12 \mathrm{~h}$ and water $(30 \mathrm{~mL})$ was added to quench the reaction. The mixture was extracted with dichloromethane $(20 \mathrm{~mL})$ twice. The organic extract was washed with saturated aqueous sodium thiosulfate $(30 \mathrm{~mL})$ twice, saturated aqueous sodium bicarbonate $(30 \mathrm{~mL})$ twice, and water $(30 \mathrm{~mL})$ twice. The mixtures were dried using anhydrous sodium sulfate and concentrated under vacuum. The residue was further purified by silica gel column chromatography (1:6 ethyl EtOAc/hexane) to obtain 3 (white solid, $1.56 \mathrm{~g}, 75.1 \%$ ).

\subsection{2. (E)-Methyl-3-methoxy-2-(2-phenoxyphenyl)acrylate (3)}

A mixture of intermediate $2(1.00 \mathrm{~g}, 4.13 \mathrm{mmol})$, arylboronic acid $(1.23 \mathrm{~g}, 5.37 \mathrm{mmol}), \mathrm{Pd}\left(\mathrm{PPh}_{3}\right)_{4}$ $(0.24 \mathrm{~g}, 0.21 \mathrm{mmol})$ and $\mathrm{K}_{3} \mathrm{PO}_{4}(2.63 \mathrm{~g}, 12.40 \mathrm{mmol})$ was dissolved into a mixture of $6 \mathrm{~mL}$ dioxane and $2 \mathrm{~mL}$ water, and this mixture was stirred under nitrogen atmosphere at $90{ }^{\circ} \mathrm{C}$ for $10 \mathrm{~h}$. Then, the reaction mixture was cooled down, poured into ice water $(100 \mathrm{~mL})$ and extracted with EtOAc (30 $\mathrm{mL}$ ) twice. The mixture was dried using anhydrous sodium sulfate and the solvent was evaporated under vacuum. Next, the residue was purified by silica gel column chromatography (1:8 EtOAc /hexane) to obtain 4 (white solid, $1.56 \mathrm{~g}, 90.3 \%$ ).

\subsection{3. (E)-Methyl-3-methoxy-2-(2-hydroxyphenyl)acrylate (4)}

A mixture of $10 \mathrm{wt}$. \% Pd/C $(0.18 \mathrm{~g}, 0.085 \mathrm{mmol})$ was added into a solution of compound 4 $(1.00 \mathrm{~g}, 3.36 \mathrm{mmol})$ in $30 \mathrm{~mL}$ EtOAc. The mixed solution was then stirred under a $\mathrm{H}_{2}$ atmosphere ( $1 \mathrm{~atm}$ ) at $35^{\circ} \mathrm{C}$ for $12 \mathrm{~h}$. Then, the reaction mixture was filtered and the filtrate was concentrated under vacuum. The residue was further purified by silica gel column chromatography (1:3 EtOAc/hexane) to afford $4(1.34 \mathrm{~g}, 95.4 \%)$.

\subsubsection{Methyl (E)-2-\{2-[(6-chloro-2-phenylpyrimidin-4-yl)oxy]phenyl\}-3-methoxyacrylate (6)}

A mixture of intermediate $4(1.00 \mathrm{~g}, 4.80 \mathrm{mmol})$, fenclorim $5(2.16 \mathrm{~g}, 9.60 \mathrm{mmol})$, and $\mathrm{K}_{2} \mathrm{CO}_{3}$ $(1.33 \mathrm{~g}, 9.60 \mathrm{mmol})$ was dissolved in dry dimethylformamid (DMF, $50 \mathrm{~mL})$ at $0{ }^{\circ} \mathrm{C}$ under nitrogen atmosphere. The mixture was then stirred at this temperature for a further $12 \mathrm{~h}$. The mixture was then poured into ice water $(100 \mathrm{~mL})$ and extracted with EtOAc $(20 \mathrm{~mL})$ twice. The organic extract was evaporated under vacuum and the residue was purified by silica gel column chromatography (1:7 EtOAc/hexane) to afford compound 6 (2.99 g, 79\%). Compound 6 was a white solid with the following characteristics: m.p. $121-122{ }^{\circ} \mathrm{C} ;{ }^{1} \mathrm{H} \mathrm{NMR}\left(300 \mathrm{MHz}, \mathrm{CDCl}_{3}\right) \delta$ [ppm]: $3.54\left(\mathrm{~s}, 3 \mathrm{H}, \mathrm{OCH}_{3}\right)$, $3.67\left(\mathrm{~s}, 3 \mathrm{H}, \mathrm{OCH}_{3}\right), 6.63(\mathrm{~s}, 1 \mathrm{H}, \mathrm{PyH}), 7.24-7.26(\mathrm{~m}, 2 \mathrm{H}, \mathrm{ArH}), 7.32-7.35(\mathrm{~m}, 2 \mathrm{H}, \mathrm{ArH}), 7.39-7.44(\mathrm{~m}, 4 \mathrm{H}$, $\mathrm{ArH}+\mathrm{CH}), 8.28-8.32(\mathrm{~m}, 2 \mathrm{H}, \mathrm{ArH}) ;{ }^{13} \mathrm{C} \mathrm{NMR}\left(75 \mathrm{MHz}, \mathrm{CDCl}_{3}\right) \delta$ [ppm]:170.5, 167.4, 165.0, 162.0, 161.0, 150.3, 135.7, 132.7, 131.6, 129.1, 128.7, 128.5, 126.1, 125.9, 122.0, 107.2, 104.5, 61.8, 50.8 HRMS (ESI+) $m / z$ : $397.0950\left([\mathrm{M}+\mathrm{H}]^{+}\right)$; found: 397.0946 .

\subsubsection{6-chloro-N-2-diphenylpyrimidin-4-amine (7)}

A mixture of fenclorim $5(1.00 \mathrm{~g}, 4.44 \mathrm{mmol})$, phenylamine $(0.34 \mathrm{~g}, 3.70 \mathrm{mmol})$ and TEA $(0.50 \mathrm{~g}$, $4.44 \mathrm{mmol}$ ), was dissolved in dry $\mathrm{N}$-methylpyrolidin-2-one (NMP, $20 \mathrm{~mL}$ ) at $120{ }^{\circ} \mathrm{C}$ under nitrogen atmosphere for $24 \mathrm{~h}$. The mixture was then cooled to room temperature, and a mixture of EtOAc $(20 \mathrm{~mL})$ and saturated sodium chloride solution $(20 \mathrm{~mL})$ was added. Then, this mixture was stirred for $30 \mathrm{~min}$. The organic layer was separated, dried using anhydrous sodium sulfate, filtered, and concentrated under a vacuum. Next, the residue was purified using silica gel column chromatography (1:6 EtOAc/hexane) to obtain compound $7(0.90 \mathrm{~g}, 72 \%)$. Compound 7 was a white solid with the following characteristics: m.p. 95-96 ${ }^{\circ} \mathrm{C} ;{ }^{1} \mathrm{H}$ NMR $\left(300 \mathrm{MHz}, \mathrm{CDCl}_{3}\right) \delta$ [ppm]: 6.61 (s, 1H, PyH), $6.92(\mathrm{~s}, 1 \mathrm{H}, \mathrm{NH}), 7.21-7.27$ $(\mathrm{m}, 1 \mathrm{H}, \mathrm{ArH}), 7.36-7.50(\mathrm{~m}, 7 \mathrm{H}, \mathrm{ArH}), 8.37-8.41(\mathrm{~m}, 2 \mathrm{H}, \mathrm{ArH}) ;{ }^{13} \mathrm{C} \mathrm{NMR}\left(75 \mathrm{MHz}, \mathrm{CDCl}_{3}\right) \delta$ [ppm]: $164.9,162.1,160.9,137.5,136.5,131.1,129.5,128.4,128.3,125.4,122.6,100.5$; HRMS (ESI+) m/z: 282.0790 $\left([\mathrm{M}+\mathrm{H}]^{+}\right)$; found: 282.0793 . 


\subsection{Structural Determination}

Colorless single crystals of compounds $\mathbf{6}$ and $\mathbf{7}$ were obtained by slowly evaporating a methanol solution containing pure compounds $\mathbf{6}$ and $\mathbf{7}$ at room temperature. Single crystal X-ray diffraction data of compounds 6 and 7 were obtained using a SuperNova, Dual, $\mathrm{Cu}$ at zero, AtlasS2 diffractometer (Agilent, CA, USA) equipped with MoK $\alpha$ radiation $(\lambda=1.54184 \AA)$ at $100.00(10) \mathrm{K}$. The crystal dimensions of compounds 6 and 7 were $0.11 \times 0.11 \times 0.08 \mathrm{~mm}^{3}$ and $0.14 \times 0.13 \times 0.12 \mathrm{~mm}^{3}$, respectively.

A total of 3608 reflections were collected by employing an $\omega$ scan mode for compound 6, 6797 of which were independent with $R_{\text {int }}=0.1240, R_{\text {sigma }}=0.1384$. The final $R_{1}$ was $0.0697(I>2 \sigma(I))$ and wR2 was 0.1869 for compound 6 . A total of 4819 reflections were collected by using $\omega$ scan mode for compound 7, 1795 of which were unique with $R_{\text {int }}=0.0317$ and $R_{\text {sigma }}=0.0245$. The final $R_{1}$ was 0.0372 $(I>2 \sigma(I))$ and $\mathrm{wR}_{2}$ was 0.0990 . The structures of compounds 6 and 7 were solved using the ShelXT structure solution program by Intrinsic Phasing and refined with the ShelXL refinement package via Least Squares minimization, using Olex2 [24-26].

The crystal data and structure refinement details of the compounds 6 and 7 are provided in Table 1. The crystallographic data for compounds $\mathbf{6}$ and 7 are available from the Cambridge Crystallographic Data Centre (CCDC) (www.ccdc.cam.ac.uk/structures/), with CCDC No. 1878381 and 1870401 , respectively.

Table 1. Crystal data and structural refinements of compounds 6 and 7.

\begin{tabular}{|c|c|c|}
\hline Compound & 6 & 7 \\
\hline CCDC No. & 1878381 & 1870401 \\
\hline Empirical formula & $\mathrm{C}_{21} \mathrm{H}_{17} \mathrm{ClN}_{2} \mathrm{O}_{4}$ & $\mathrm{C}_{16} \mathrm{H}_{12} \mathrm{ClN}_{3}$ \\
\hline Formula weight & 396.82 & 281.74 \\
\hline Temperature/K & $100.00(10)$ & $100.00(10)$ \\
\hline Crystal system & monoclinic & monoclinic \\
\hline Space group & $\mathrm{P} 2{ }_{1} / \mathrm{c}$ & $\mathrm{Cc}$ \\
\hline $\mathrm{a} / \AA$ & $8.4842(6)$ & $10.2347(7)$ \\
\hline $\mathrm{b} / \AA$ & $24.457(2)$ & $18.3224(10)$ \\
\hline$c / \AA$ & $8.9940(6)$ & $7.2447(4)$ \\
\hline$\alpha /^{\circ}$ & 90 & 90 \\
\hline$\beta /^{\circ}$ & $96.305(6)$ & $92.266(6)$ \\
\hline$\gamma /{ }^{\circ}$ & 90 & 90 \\
\hline Volume $/ \AA^{3}$ & $1855.0(2)$ & $1357.50(14)$ \\
\hline $\mathrm{Z}$ & 4 & 4 \\
\hline$\rho$ calcg $/ \mathrm{cm}^{3}$ & 1.421 & 1.379 \\
\hline$\mu / \mathrm{mm}^{-1}$ & 2.092 & 2.418 \\
\hline $\mathrm{F}(000)$ & 824.0 & 584.0 \\
\hline Crystal size $/ \mathrm{mm}^{3}$ & $0.11 \times 0.11 \times 0.08$ & $0.14 \times 0.13 \times 0.12$ \\
\hline Radiation & $\mathrm{CuK} \alpha(\lambda=1.54184)$ & $\mathrm{CuK} \alpha(\lambda=1.54184)$ \\
\hline $2 \Theta$ range for data collection $/^{\circ}$ & 7.228 to 177.332 & 9.654 to 148.926 \\
\hline Index ranges & $-10 \leq \mathrm{h} \leq 10,-29 \leq \mathrm{k} \leq 30,-8 \leq 1 \leq 10$ & $-12 \leq \mathrm{h} \leq 8,-22 \leq \mathrm{k} \leq 21,-8 \leq 1 \leq 8$ \\
\hline Reflections collected & 6427 & 4819 \\
\hline Independent reflections & $3608\left[R_{\text {int }}=0.1240, R_{\text {sigma }}=0.1384\right]$ & $1795\left[R_{\text {int }}=0.0317, R_{\text {sigma }}=0.0245\right]$ \\
\hline Data/restraints/parameters & $3608 / 54 / 255$ & $1795 / 2 / 181$ \\
\hline Goodness-of-fit on $\mathrm{F}^{2}$ & 1.053 & 1.053 \\
\hline Final $\mathrm{R}$ indexes $[I \geq 2 \sigma(I)]$ & $\mathrm{R}_{1}=0.0697, \mathrm{wR}_{2}=0.1650$ & $\mathrm{R}_{1}=0.0372, \mathrm{wR}_{2}=0.0985$ \\
\hline Final R indexes [all data] & $\mathrm{R}_{1}=0.0835, \mathrm{wR}_{2}=0.1869$ & $\mathrm{R}_{1}=0.0376, \mathrm{wR}_{2}=0.0990$ \\
\hline Largest diff. peak/hole/ e $\AA^{-3}$ & $1.17 /-1.33$ & $0.22 /-0.30$ \\
\hline
\end{tabular}

\subsection{Fungicidal Activity}

The in vivo fungicidal activity ( $\mathrm{EC}_{50}$ values) of compounds 6, 7, fenclorim, and pyrimethanil against $P$. cubensis were tested according to methods in the reported literature $[27,28]$. The fungicidal activities of compounds 6, 7, fenclorim and pyrimethanil against P. cubensis, E. cichoracearum, B. graminis, 
R. solani, and P. polysora were tested at different concentrations in vitro using methods reported previously [5].

\section{Results and Discussion}

\subsection{Synthesis and Spectroscopic Properties}

The synthetic routes for compounds 6 and 7 are described in Scheme 2; Scheme 3. Intermediate 2 was synthesized through the nucleophilic substitution of the acrylate group of methyl (E)-3-methoxyacrylate by $\mathrm{N}$-iodosuccinimide. The formation of intermediate $\mathbf{3}$ from intermediate $\mathbf{2}$ and arylboronic acid was achieved via the Suzuki-Miyaura cross-coupling reaction. The synthesis of intermediate 4 , the precursor of compound 6 , was achieved via the reduction of intermediate 4 using $\mathrm{Pd}\left(\mathrm{PPh}_{3}\right)_{4}$ as the catalyst under nitrogen atmosphere. Compound 6 was afforded by the condensation of intermediate 4 and fenclorim 5 . Compound 7 was synthesized by a one-step condensation method, using fenclorim and phenylaline as starting materials.

The chemical structures of compound $\mathbf{6}$ and $\mathbf{7}$ were characterized by NMR spectroscopy, HRMS, and $\mathrm{X}$-ray diffraction analysis. For compound $\mathbf{6}$, signals corresponding to $\mathrm{C}-\mathrm{H}$ protons in the phenyl ring and pyrimidine were observed at $\delta 7.21-8.41$ and $\delta 6.61$, respectively; signals corresponding to the $\mathrm{C}-\mathrm{H}$ proton to $\mathrm{N}-\mathrm{H}$ proton in imino group were observed $\delta 6.69$. For compound 7 , signals corresponding to $\mathrm{C}-\mathrm{H}$ protons in methoxyl groups were observed at $\delta 3.54$ and $\delta 3.67$, respectively; signals corresponding to the $\mathrm{C}-\mathrm{H}$ proton to $\mathrm{C}-\mathrm{H}$ proton in pyrimidine ring were observed at $\delta 6.63$, and signals corresponding to the $\mathrm{C}-\mathrm{H}$ proton in the phenyl ring were at $\delta 7.24-8.32$. In the compound $6{ }^{13} \mathrm{C}-\mathrm{NMR}$ spectra, chemical shifts of carbons that resonated at $\delta 107.18-170.47$ were assigned to carbons in the phenyl ring and pyridine ring. The chemical shifts of carbons that resonated at $\delta 51.59$ and 61.93 , respectively, were assigned to the carbons in methoxyl groups. The signal at $\delta 104.46$ can be assigned to carbon (C-7) in the acrylate group. In the ${ }^{13} \mathrm{C}-\mathrm{NMR}$ spectra of compound 7 , chemical shifts linked to aromatic rings (phenyl ring and pyrimidine ring) appeared at 100.5-164.94. All HRMS data for compounds 6 and 7 were well-matched with theoretical values calculated from their chemical formula.

\subsection{Crystal Structures of Compounds 6 and 7}

Compounds 6 and 7 both crystallized in the monoclinic system, with a $\mathrm{P} 2_{1} / \mathrm{c}$ space group and Cc space group, respectively. The molecular structures of compounds $\mathbf{6}$ and $\mathbf{7}$ are described in Figure 2a,b, and selected molecular structure parameters, including bond lengths and bond angles for compound 6 and $\mathbf{7}$, are listed in Tables 2 and 3, respectively. Packing diagrams of compounds $\mathbf{6}$ and $\mathbf{7}$ are shown in Figure $3 \mathrm{a}, \mathrm{b}$ respectively.

The selected bond lengths and bond angles of the phenyl ring and pyrimidine ring in the crystal structure of compounds $\mathbf{6}$ and 7 are similar to those of compounds reported in the literature, which are in accordance with normal ranges [29-32]. According to the data in Figure 2a, compound 6 is composed of four molecular moieties (two phenyl rings, a chlorine-substituted pyrimidine ring, and a (Z)-methyl 2-iodo-3-methoxyacrylate group). The phenyl ring, formed by $C(16)-C(17)-C(18)-C(19)-C(20)-C(21)$, and the pyrimidine ring, formed by $\mathrm{C}(15)-\mathrm{N}(2)-\mathrm{C}(14)-\mathrm{C}(13)-\mathrm{C}(12)-\mathrm{N}(1)$, are linked by a $\mathrm{C}(15)-\mathrm{C}(16)$ bridge. The bond length of $C(15)-C(16)$, a single bond, is 1.556(5) $\AA$, and the torsion angle of $N(2)-C(15)-C(16)$ is $119.8(3) \AA$. The phenyl ring, defined as $C(1)-C(2)-C(3)-C(4)-C(5)-C(6)$, and the pyrimidine ring, are linked by an oxygen atom. The bond angle of $C(12)-O(1)-C(1)$ is $115.3(3) \AA$. The acrylate moiety assumes an $E$ configuration double bond $C(7)=C(10)(1.391(6) \AA)$ of the vinyl group. The bond lengths of $\mathrm{C}(8)-\mathrm{O}(3)$ in the acrylate group are 1.229(6) $\AA$, which is similar to the general length reported for $\mathrm{C}=\mathrm{O}$, indicating that it is a double bond [33-35]. The dihedral angles between the mean planes of $C(15), N(2), C(14), C(13), C(12), N(1)$ with $C(16), C(17), C(18), C(19), C(20)$, $\mathrm{C}(21), \mathrm{C}(19)$ and $\mathrm{C}(1), \mathrm{C}(2), \mathrm{C}(3), \mathrm{C}(4), \mathrm{C}(5), \mathrm{C}(6)$ are $3.368(109)^{\circ}$ and $66.294(120)^{\circ}$, respectively.

Compound 7 is composed of a chlorine-substituted pyrimidine ring and two phenyl rings (Figure $2 b$ ). The phenyl ring, formed by $C(1)-C(2)-C(3)-C(4)-C(5)-C(6)$, is linked with the pyrimidine 
ring, formed by $\mathrm{C}(7)-\mathrm{N}(1)-\mathrm{C}(8)-\mathrm{C}(9)-\mathrm{C}(10)-\mathrm{N}(2)$ via a $\mathrm{C}(1)-\mathrm{C}(7)$ bridge. The bond length of $\mathrm{C}(1)-\mathrm{C}(7)$ is $1.482(4) \AA$ and the torsion angle of $\mathrm{N}(2)-\mathrm{C}(7)-\mathrm{C}(1)$ is $117.3(2) \AA$. The pyrimidine ring above and phenyl ring defined as $C(11)-C(12)-C(13)-C(14)-C(15)-C(16)$ are linked by a nitrogen atom, with a torsion angle $\mathrm{C}(10)-\mathrm{N}(3)-\mathrm{C}(11)$ of $126.5(2) \AA$. The dihedral angles between the mean planes of $\mathrm{C}(7)$, $\mathrm{N}(1), \mathrm{C}(8), \mathrm{C}(9), \mathrm{C}(10), \mathrm{N}(2)$ with C(1), C(2), C(3), C(4), C(5), C(6)and C(11), C(12), C(13), C(14), C(15), $\mathrm{C}(16)$ are $8.447(74)^{\circ}$ and $45.236(88)^{\circ}$, respectively.

Based on whole structural analysis, molecule 6 , forms $\mathrm{C}-\mathrm{H} \cdots \mathrm{N}$ (symmetry code: $1-\mathrm{x}, 1-\mathrm{y}, 1-\mathrm{z}$ ) and $\mathrm{C}-\mathrm{H} \cdots \mathrm{O}$ hydrogen bonding interactions (symmetry code: $1+\mathrm{x}, \mathrm{y}, \mathrm{z}$ ) with the phenyl $\mathrm{C}$ atom (Table 4), to from three-dimensional networks. The C $\cdots \mathrm{N}$ distances between donor (D) and acceptor (A) molecules were 3.341(6) $\AA$ for $\mathrm{C}(5)-\mathrm{H}(5) \cdots \mathrm{N}(2)$, and 2.8711(16) $\AA$ for $\mathrm{C}(11)-\mathrm{H}(11 \mathrm{~B}) \cdots \mathrm{O}(3)$, respectively. The distances between hydrogen atom and acceptor atom were $2.53 \AA$ for $\mathrm{H}(5) \cdots \mathrm{N}(2)$, and $2.30 \AA$ for $\mathrm{H}(11 \mathrm{~B}) \cdots \mathrm{O}(3)$, respectively. Both of the bond lengths were shorter than sum of van der Waals radii (2.66 ̊̊ for $\mathrm{H}(5) \cdots \mathrm{N}(2)$ and $2.63 \AA$ for $\mathrm{H}(11 \mathrm{~B}) \cdots \mathrm{O}(3))$ [36]. As shown in Table 5, $\mathrm{N}(3)-\mathrm{H}(3) \cdots \mathrm{N}(1)$

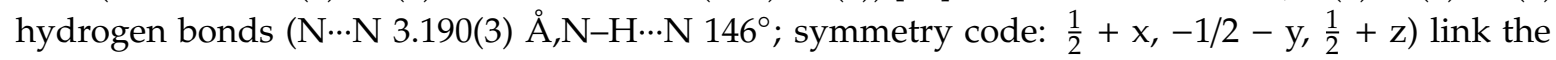
neighboring molecules of compound 7 to form a three-dimensional framework. Weak hydrogen bonds $\mathrm{C}(2)-\mathrm{H}(2) \cdots \mathrm{N}(1), \mathrm{C}(6)-\mathrm{H}(6) \cdots \mathrm{N}(2)$, and $\mathrm{C}(12)-\mathrm{H}(12) \cdots \mathrm{N}(2)$ also stabilize the crystal structure.

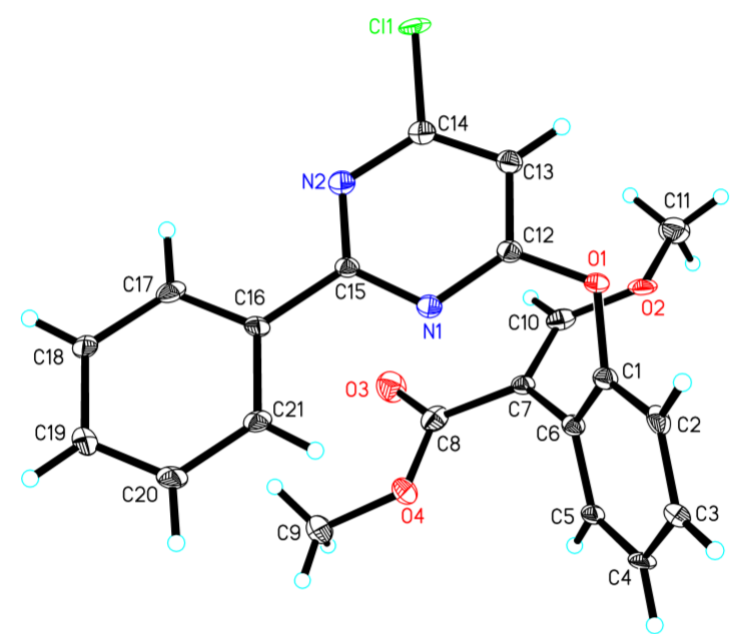

(a)

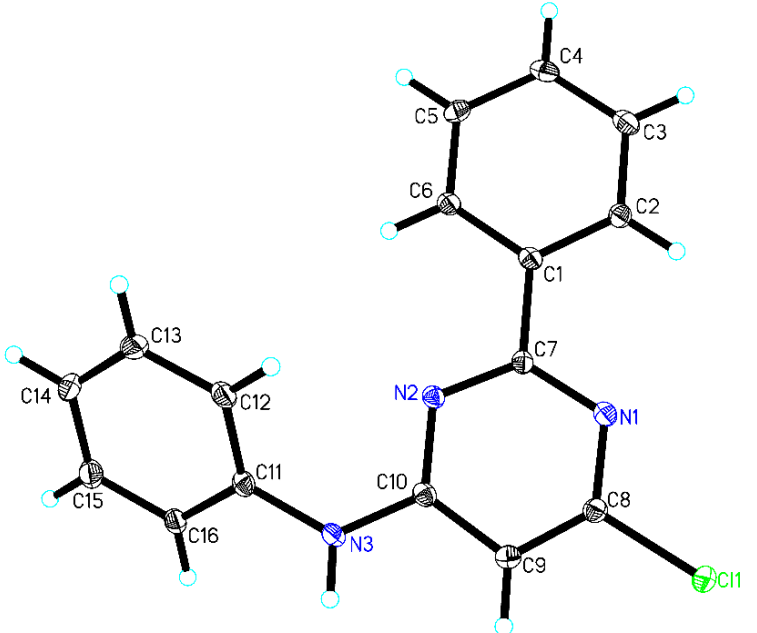

(b)

Figure 2. Crystal structure of compound 6 (2a) and 7 (2b). 
Table 2. Selected bond lengths $(\AA)$ and bond angles $\left(^{\circ}\right)$ for compound 6 .

\begin{tabular}{|c|c|c|c|}
\hline Bond & Distance (Å) & Bond & Distance (Å) \\
\hline $\mathrm{C}(12)-\mathrm{O}(1)$ & $1.338(5)$ & $\mathrm{C}(1)-\mathrm{O}(1)$ & $1.362(5)$ \\
\hline $\mathrm{C}(10)-\mathrm{O}(2)$ & $1.386(6)$ & $\mathrm{C}(15)-\mathrm{N}(1)$ & $1.338(5)$ \\
\hline $\mathrm{C}(11)-\mathrm{O}(2)$ & $1.472(6)$ & $\mathrm{C}(15)-\mathrm{N}(2)$ & $1.308(6)$ \\
\hline $\mathrm{C}(8)-\mathrm{O}(4)$ & $1.353(6)$ & $\mathrm{C}(14)-\mathrm{N}(2)$ & $1.396(6)$ \\
\hline $\mathrm{C}(9)-\mathrm{O}(4)$ & $1.537(6)$ & $\mathrm{C}(8)-\mathrm{O}(3)$ & $1.229(6)$ \\
\hline $\mathrm{C}(12)-\mathrm{N}(1)$ & $1.412(5)$ & $\mathrm{C}(14)-\mathrm{Cl}(1)$ & $1.692(5)$ \\
\hline$C(15)-C(16)$ & $1.556(5)$ & $C(14)-C(13)$ & $1.367(6)$ \\
\hline$C(1)-C(6)$ & $1.397(6)$ & $C(5)-C(4)$ & $1.380(6)$ \\
\hline$C(12)-C(13)$ & $1.362(6)$ & $C(20)-C(19)$ & $1.371(6)$ \\
\hline$C(15)-C(16)$ & $1.556(5)$ & $C(7)-C(10)$ & $1.391(6)$ \\
\hline Angle & $\left({ }^{\circ}\right)$ & Angle & $\left({ }^{\circ}\right)$ \\
\hline $\mathrm{C}(12)-\mathrm{O}(1)-\mathrm{C}(1)$ & 115.3(3) & $\mathrm{O}(1)-\mathrm{C}(12)-\mathrm{C} 13$ & $112.2(4)$ \\
\hline $\mathrm{C}(10)-\mathrm{O}(2)-\mathrm{C}(11)$ & $116.7(4)$ & $\mathrm{N}(1)-\mathrm{C}(15)-\mathrm{C} 16$ & $118.7(4)$ \\
\hline $\mathrm{C}(8)-\mathrm{O}(4)-\mathrm{C}(9)$ & $118.7(4)$ & $\mathrm{N}(2)-\mathrm{C}(15)-\mathrm{N} 1$ & $121.5(4)$ \\
\hline $\mathrm{C}(15)-\mathrm{N}(1)-\mathrm{C}(12)$ & $117.7(4)$ & $\mathrm{N}(2)-\mathrm{C}(15)-\mathrm{C} 16$ & $119.8(3)$ \\
\hline$C(15)-N(2)-C(14)$ & $118.2(4)$ & $\mathrm{O}(1)-\mathrm{C}(1)-\mathrm{C} 2$ & $115.0(4)$ \\
\hline $\mathrm{O}(1)-\mathrm{C}(12)-\mathrm{N}(1)$ & $122.2(4)$ & $\mathrm{O}(1)-\mathrm{C}(1)-\mathrm{C}(6)$ & $119.9(4)$ \\
\hline$N(2)-C(14)-C(11)$ & 118.7(3) & $\mathrm{C}(13)-\mathrm{C}(14)-\mathrm{N}(2)$ & $126.4(4)$ \\
\hline $\mathrm{O}(4)-\mathrm{C}(8)-\mathrm{C}(7)$ & $115.5(3)$ & $\mathrm{O}(3)-\mathrm{C}(8)-\mathrm{O}(4)$ & $118.3(4)$ \\
\hline
\end{tabular}

Table 3. Selected bond lengths $(\AA)$ and bond angles $\left(^{\circ}\right)$ for compound 7.

\begin{tabular}{|c|c|c|c|}
\hline Bond & Distance (Å) & Bond & Distance (Å) \\
\hline $\mathrm{Cl}(1)-\mathrm{C}(8)$ & $1.732(3)$ & $C(1)-C(2)$ & $1.399(4)$ \\
\hline $\mathrm{N}(3)-\mathrm{C}(11)$ & $1.413(4)$ & $C(1)-C(6)$ & $1.401(4)$ \\
\hline $\mathrm{N}(3)-\mathrm{C}(10)$ & $1.356(4)$ & $C(5)-C(6)$ & $1.384(4)$ \\
\hline $\mathrm{N}(1)-\mathrm{C}(7)$ & $1.343(4)$ & $C(5)-C(4)$ & $1.389(4)$ \\
\hline $\mathrm{N}(1)-\mathrm{C}(8)$ & $1.339(4)$ & $C(9)-C(8)$ & $1.360(4)$ \\
\hline $\mathrm{N}(2)-\mathrm{C}(7)$ & $1.337(3)$ & $C(9)-C(10)$ & $1.412(4)$ \\
\hline $\mathrm{N}(2)-\mathrm{C}(10)$ & $1.341(4)$ & $C(15)-C(14)$ & $1.390(4)$ \\
\hline$C(11)-C(16)$ & $1.393(4)$ & $C(2)-C(3)$ & $1.383(4)$ \\
\hline$C(11)-C(12)$ & $1.395(4)$ & $\mathrm{C}(3)-\mathrm{C}(4)$ & $1.395(4)$ \\
\hline $\mathrm{C}(1)-\mathrm{C}(7)$ & $1.482(4)$ & $C(14)-C(13)$ & $1.383(5)$ \\
\hline Angle & $\left({ }^{\circ}\right)$ & Angle & $\left({ }^{\circ}\right)$ \\
\hline$C(10)-N(3)-C(11)$ & $126.5(2)$ & $\mathrm{N}(2)-\mathrm{C}(7)-\mathrm{C}(1)$ & $117.3(2)$ \\
\hline $\mathrm{C}(8)-\mathrm{N}(1)-\mathrm{C}(7)$ & $114.6(2)$ & $\mathrm{N}(1)-\mathrm{C}(8)-\mathrm{Cl}(1)$ & $114.9(2)$ \\
\hline $\mathrm{C}(7)-\mathrm{N}(2)-\mathrm{C}(10)$ & $117.3(2)$ & $\mathrm{N}(1)-\mathrm{C}(8)-\mathrm{C}(9)$ & $125.2(3)$ \\
\hline $\mathrm{C}(16)-\mathrm{C}(11)-\mathrm{N}(3)$ & $118.5(2)$ & $\mathrm{C}(9)-\mathrm{C}(8)-\mathrm{Cl}(1)$ & $119.9(2)$ \\
\hline$C(16)-C(11)-C(12)$ & $119.6(3)$ & $\mathrm{N}(3)-\mathrm{C}(10)-\mathrm{C}(9)$ & $119.5(2)$ \\
\hline $\mathrm{C}(12)-\mathrm{C}(11)-\mathrm{N}(3)$ & $121.9(2)$ & $\mathrm{N}(2)-\mathrm{C}(10)-\mathrm{N}(3)$ & 119.4(2) \\
\hline$C(15)-C(16)-C(11)$ & $120.3(3)$ & $\mathrm{N}(2)-\mathrm{C}(10)-\mathrm{C}(9)$ & $121.1(2)$ \\
\hline$C(2)-C(1)-C(7)$ & $120.7(2)$ & $C(3)-C(2)-C(1)$ & $120.7(3)$ \\
\hline$C(2)-C(1)-C(6)$ & $118.6(3)$ & $C(2)-C(3)-C(4)$ & $120.2(3)$ \\
\hline$C(6)-C(1)-C(7)$ & $120.7(2)$ & $C(5)-C(6)-C 1)$ & $120.6(3)$ \\
\hline
\end{tabular}




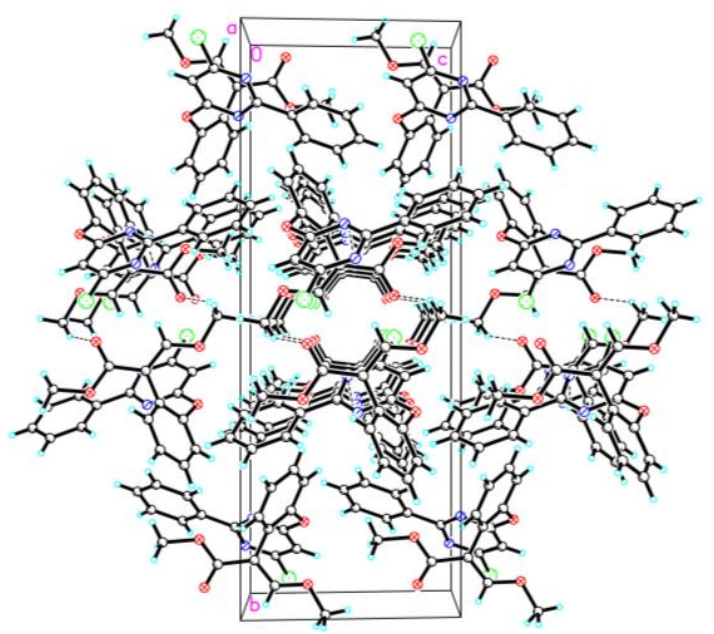

(a)

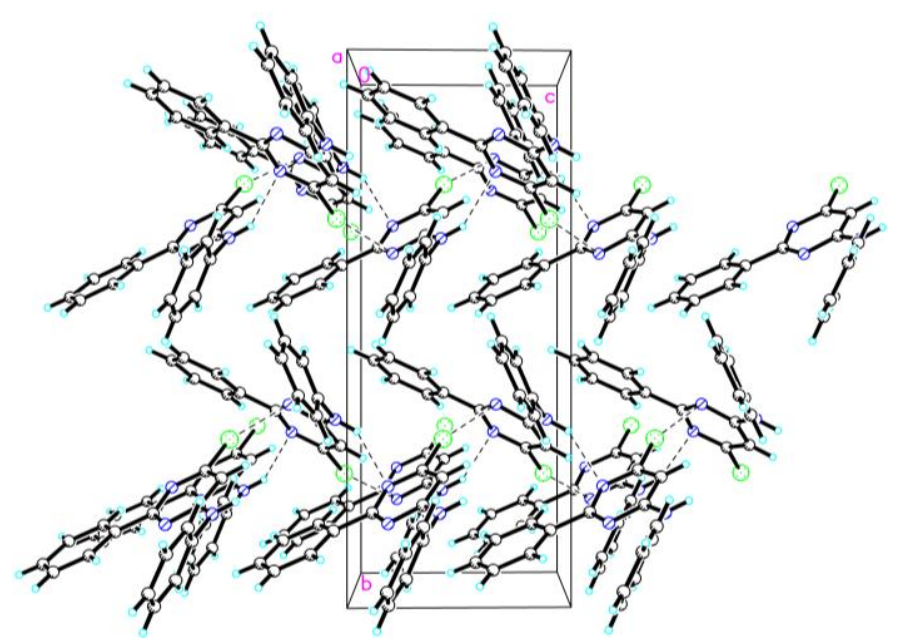

(b)

Figure 3. Packing diagram of compound 6 (3a) and 7 (3b). Dashed lines represent hydrogen bonds.

Table 4. Hydrogen bonding interactions in compound 7.

\begin{tabular}{ccccc}
\hline $\mathbf{D}-\mathbf{H} \cdots \mathbf{A}$ & $\mathbf{d}(\mathbf{D}-\mathbf{H}) /(\AA)$ & $\mathbf{d}(\mathbf{H} \cdots \mathbf{A}) /(\AA)$ & $\mathbf{d}(\mathbf{D} \cdots \mathbf{A}) /(\AA)$ & $<(\mathbf{D H A}) /\left(^{\circ}\right)$ \\
\hline $\mathrm{C}(5)-\mathrm{H}(5) \cdots \mathrm{N}(2)$ & 0.93 & 2.53 & $3.341(6)$ & 146 \\
$\mathrm{C}(11)-\mathrm{H}(11 \mathrm{~B}) \cdots \mathrm{O}(3)$ & 0.96 & 2.30 & $3.162(7)$ & 148 \\
\hline
\end{tabular}

Symmetry transformations used to generate the equivalent atoms: \#1: $1-x, 1-y, 1-z ; \# 2: 1+x, y, z$.

Table 5. Hydrogen bonding interactions in compound 6.

\begin{tabular}{ccccc}
\hline $\mathbf{D}-\mathbf{H} \cdots \mathbf{A}$ & $\mathbf{d}(\mathbf{D}-\mathbf{H}) /(\mathbf{A})$ & $\mathbf{d}(\mathbf{H} \cdots \mathbf{A}) /(\AA \mathbf{A})$ & $\mathbf{d}(\mathbf{D} \cdots \mathbf{A}) /(\AA)$ & $<(\mathbf{D H A}) /\left(^{\circ}\right)$ \\
\hline $\mathrm{N}(3)-\mathrm{H}(3) \cdots \mathrm{N}(1)$ & 0.86 & 2.44 & $3.190(3)$ & 146 \\
$\mathrm{C}(2)-\mathrm{H}(2) \cdots \mathrm{N}(1)$ & 0.93 & 2.48 & $2.802(4)$ & 100 \\
$\mathrm{C}(6)-\mathrm{H}(6) \cdots \mathrm{N}(2)$ & 0.93 & 2.50 & $2.817(4)$ & 100 \\
$\mathrm{C}(12)-\mathrm{H}(12) \cdots \mathrm{N}(2)$ & 0.93 & 2.57 & $2.930(4)$ & 104 \\
\hline
\end{tabular}

Symmetry transformations used to generate the equivalent atoms: $\frac{1}{2}+x,-1 / 2-y, \frac{1}{2}+z$. 


\subsection{Fungicidal Activities}

The in vivo fungicidal activities ( $\mathrm{EC}_{50}$ values) of compound 6 , compound 7 , positive control fenclorim and pyrimethanil against B. cinerea are listed in Table 6. Compound 6 displayed the greatest activity with an $\mathrm{EC}_{50}$ value of $20.84 \mathrm{mg} / \mathrm{L}$, which was much greater than that of compound $7(215.45 \mathrm{mg} / \mathrm{L})$, fenclorim $(319.95 \mathrm{mg} / \mathrm{L})$ and pyrimethanil $(30.72 \mathrm{mg} / \mathrm{L})$. This result indicates that the combination of the (Z)-methyl-2-iodo-3-methoxyacrylate group substituted phenoxyl group with fenclorim could improve the in vivo fungicidal activity of fenclorim against Botrytis cinerea.

Table 6. The in vivo $\mathrm{EC}_{50}$ values of compounds 6 and 7 and pyrimethanil against Botrytis cinerea.

\begin{tabular}{cccc}
\hline Comp. & $\mathrm{EC}_{\mathbf{5 0}}( \pm \mathrm{SD})(\mathbf{m g} / \mathrm{L})$ & Comp. & $\mathrm{EC}_{\mathbf{5 0}}( \pm \mathrm{SD})(\mathbf{m g} / \mathrm{L})$ \\
\hline $\mathbf{6}$ & $20.84 \pm 4.04$ & 7 & $215.45 \pm 55.43$ \\
fenclorim & $319.95 \pm 30.62$ & pyrimethanil & $30.72 \pm 3.78$ \\
\hline
\end{tabular}

To further study the fungicidal activity of compounds 6 and 7 , the in vitro inhibitory rate of compounds 6, 7, fenclorim, and pyrimethanil against P. cubensis, E. cichoracearum, B. graminis, R. Solani, and P. polysora were evaluated at different concentrations (Table 7). At $200 \mathrm{mg} / \mathrm{L}$, compound 6 displayed the strongest fungicidal activity against P.cubensis ( $94.00 \%$ control) and against R. Solani ( $91.67 \%$ control), while compound 7 showed the strongest fungicidal activity against E. cichoracearum $(91.00 \%$ control), B. graminis ( $90.67 \%$ control) and P. polysora (90.67\% control). Furthermore, fenclorim exhibited no activity against the E. cichoracearum control and pyrimethanil only displayed good fungicidal activity against $P$. cubensis $(89.00 \%$ control). As the concentration decreased, most of the fungicidal activity of these compounds brought to gradually. Surprisingly, compound 6 exhibited $80.33 \%$ activity of that of the control against P. cubensis, when pyrimethanil displayed only $20.67 \%$ of that of the control, when at $25 \mathrm{mg} / \mathrm{L}$. These results revealed that the combination of active groups in commercial fungicides with the lead fenclorim could improve the in vitro fungicidal activity of fenclorim significantly.

Table 7. The in vitro fungicidal activities of compounds 6 and 7.

\begin{tabular}{|c|c|c|c|c|c|c|}
\hline \multirow{2}{*}{ Compounds } & \multirow{2}{*}{$\begin{array}{c}\text { Dose } \\
(\mathrm{mg} / \mathrm{L})\end{array}$} & P. Cubensis & E. Cichoracearum & B. Graminis & R. Solani & P. Polysora \\
\hline & & \multicolumn{5}{|c|}{ Inhibitory Rate (\%) } \\
\hline \multirow{3}{*}{6} & 200 & $94.00 \pm 1.73$ & $1.67 \pm 2.88$ & $40.67 \pm 1.15$ & $91.67 \pm 2.89$ & $50.00 \pm 0$ \\
\hline & 50 & $90.00 \pm 2.00$ & 0 & $41.33 \pm 1.15$ & $59.33 \pm 1.15$ & $8.33 \pm 2.89$ \\
\hline & 12.5 & $80.33 \pm 1.53$ & 0 & $27.00 \pm 1.73$ & $58.33 \pm 2.89$ & 0 \\
\hline \multirow{4}{*}{7} & 200 & $93.33 \pm 2.89$ & $91.00 \pm 3.61$ & $90.67 \pm 1.15$ & $70.67 \pm 1.15$ & $90.67 \pm 2.31$ \\
\hline & 50 & $71.67 \pm 2.89$ & $89.00 \pm 3.61$ & $59.33 \pm 1.15$ & $11.67 \pm 2.89$ & $58.33 \pm 2.89$ \\
\hline & 12.5 & $26.67 \pm 2.89$ & $31.67 \pm 2.89$ & $14.00 \pm 1.73$ & $7.67 \pm 2.52$ & 0 \\
\hline & 200 & $92.33 \pm 2.52$ & 0 & $23.33 \pm 2.89$ & $26.67 \pm 2.89$ & $38.33 \pm 2.89$ \\
\hline \multirow[t]{3}{*}{ Fenclorim } & 50 & $85.67 \pm 2.08$ & 0 & $22.33 \pm 2.52$ & $28.33 \pm 2.89$ & $21.67 \pm 1.89$ \\
\hline & 12.5 & $22.33 \pm 2.52$ & 0 & 0 & $6.67 \pm 2.89$ & 0 \\
\hline & 200 & $89.00 \pm 3.61$ & $31.00 \pm 3.61$ & $28.33 \pm 2.89$ & $10 \pm 0$ & $31.33 \pm 1.15$ \\
\hline \multirow[t]{2}{*}{ Pyrimethanil } & 50 & $80.67 \pm 1.15$ & $6.00 \pm 1.73$ & $26.00 \pm 1.73$ & $9.33 \pm 1.15$ & $9.33 \pm 1.15$ \\
\hline & 12.5 & $20.67 \pm 1.15$ & 0 & $19.33 \pm 1.15$ & 0 & 0 \\
\hline
\end{tabular}

P. cubensis: Pseudoperonospora cubensis; E. cichoracearum: Erysiphe cichoracearum; B. graminis: Blumeria graminis; R. solani: Rhizoctonia solani; and P. polysora: Puccinia polysora.

\section{Conclusions}

In conclusion, two fenclorim derivatives (compounds 6 and 7) were synthesized by the linking of active sub-structures method. The chemical structures of the two compounds were confirmed by NMR spectroscopy, HRMS, and X-crystal diffraction, and their fungicidal activity against plant fungi were tested. Compound 6 displayed the greatest activity $\left(\mathrm{EC}_{50}\right.$ value of $20.84 \mathrm{mg} / \mathrm{L}$ ), which was much greater than that of pyrimethanil $(30.72 \mathrm{mg} / \mathrm{L})$ against $B$. cinerea in vivo. Additionally, compound 6 at $25 \mathrm{mg} / \mathrm{mL}$ exhibited $80.33 \%$ of the control $\mathrm{EC}_{50}$ value against $P$. cubensis, when pyrimethanil displayed 
only $20.67 \%$ control $\mathrm{EC}_{50}$ value at $25 \mathrm{mg} / \mathrm{L}$ in vitro. Moreover, compound 7 exhibited $89 \%$ of the control $\mathrm{EC}_{50}$ value against $E$. cichoracearum at $50 \mathrm{mg} / \mathrm{L}$ in vitro, while pyrimethanil only exhibited $6 \%$ of that of the control. Compounds 6 and 7 could be used further as pyrimidine fungicides in the future.

Author Contributions: Conceptualization, K.-J.X.; methodology, K.X; software, K.-J.X.; validation, K.-J.X.; formal analysis, K.-J.X.; investigation, K.-J.X.; resources, K.-J.X.; data curation, K.-J.X.; writingoriginal draft preparation, K.-J.X.; writing-review and editing, K.-J.X.; visualization, K.-J.X.; supervision, K.-J.X.; project administration, F.-P.D.; funding acquisition, F.-P.D. All authors have read and agreed to the published version of the manuscript.

Funding: This research and the APC were funded by the National Natural Science Foundation of China (No. 31772182).

Conflicts of Interest: The authors declare no conflict of interest.

\section{References}

1. Mardanova, A.; Lutfullin, M.; Hadieva, G.; Akosah, Y.; Pudova, D.; Kabanov, D.; Shagimardanova, E.; Vankov, P.; Vologin, S.; Gogoleva, N.; et al. Structure and variation of root-associated microbiomes of potato grown in alfisol. World J. Microbiol. Biotechnol. 2019, 35, 1-16. [CrossRef]

2. Liu, H.; Xia, D.G.; Hu, R.; Wang, W.; Cheng, X.; Wang, A.L.; Zhang, Q.; Lv, X.H. A bioactivity-oriented modification strategy for SDH inhibitors with superior activity against fungal strains. Pestic. Biochem. Physiol. 2020, 163, 271-279. [CrossRef] [PubMed]

3. Sarkar, C.; Saklani, B.K.; Singh, P.K.; Asthana, R.K.; Sharma, T.R. Variation in the LRR region of Pi54 protein alters its interaction with the AvrPi54 protein revealed by in silico analysis. PLoS ONE 2019, 14, e0224088. [CrossRef] [PubMed]

4. Xavier, W.D.; de Souza Silva, J.V.; Guimaraes, C.M.; Sousa Ferreira, J.L.; Turozi, T.A.; Colodel, S. Use of copper-based pesticides to control fungal diseases of soybean in Northern Brazil. J. Exp. Agric. Int. 2019, 33, 1-10. [CrossRef]

5. Zhang, X.; Lei, P.; Sun, T.; Jin, X.; Yang, X.; Ling, Y. Design, Synthesis, and fungicidal activity of novel thiosemicarbazide derivatives containing piperidine fragments. Molecules 2017, 22, 2085. [CrossRef]

6. Da Rocha Neto, A.C.; Luiz, C.; Maraschin, M.; Di Piero, R.M. Efficacy of salicylic acid to reduce Penicillium expansum inoculum and preserve apple fruits. Int. J. Food Microbiol. 2016, 221, 54-60. [CrossRef]

7. Matsuzaki, Y.; Yoshimoto, Y.; Arimori, S.; Kiguchi, S.; Harada, T.; Iwahashi, F. Discovery of metyltetraprole: Identification of tetrazolinone pharmacophore to overcome QoI resistance. Bioorg. Med. Chem. 2020, 28, 115211. [CrossRef]

8. Odilbekov, F.; Edin, E.; Mostafanezhad, H.; Coolman, H.; Grenville-Briggs, L.J.; Liljeroth, E. Within-season changes in Alternaria solani populations in potato in response to fungicide application strategies. Eur. J. Plant Pathol. 2019, 155, 953-965. [CrossRef]

9. Vaghefi, N.; Hay, F.S.; Kikkert, J.R.; Pethybridge, S.J. Genotypic diversity and resistance to azoxystrobin of Cercospora beticola on processing table beet in New York. Plant Dis. 2016, 100, 1466-1473. [CrossRef]

10. Zhang, H.Y.; Li, M. Transcriptional profiling of ESTs from the biocontrol fungus Chaetomium cupreum. Sci. World J. 2012, 1-7.

11. Zhao, J.; Bi, Q.; Wu, J.; Lu, F.; Han, X.; Wang, W. Occurrence and management of fungicide resistance in Botrytis cinerea on tomato from greenhouses in Hebei, China. J. Phytopathol. 2019, 167, 413-421. [CrossRef]

12. Zheng, W.N.; Zhu, Z.Y.; Deng, Y.N.; Wu, Z.C.; Zhou, Y.; Zhou, X.M.; Bai, L.Y.; Deng, X.L. Synthesis, Crystal structure, herbicide safening, and antifungal activity of $N$-(4,6-dichloropyrimidine-2-yl) benzamide. Crystals 2018, 8, 75. [CrossRef]

13. Deng, X.L.; Zheng, W.N.; Zhou, X.M.; Bai, L.Y. The effect of salicylic acid and 20 substituted molecules on alleviating metolachlor herbicide injury in rice (Oryza sativa). Agronomy 2020, 10, 317. [CrossRef]

14. Swiecilo, A.; Krzepilko, A.; Michalek, S. Evaluation of azoxystrobin toxicity to saprophytic fungi and radish in the early stages of growth. Ecol. Chem. Eng. A 2018, 25, 81-92.

15. Berry, E.A.; Huang, L.S. Conformationally linked interaction in the cytochrome bc1 complex between inhibitors of the Qo site and the Rieske iron-sulfur protein. Biochim. Biophys. Acta-Bioenerg. 2011, 1807, 1349-1363. [CrossRef] 
16. Tang, R.; Tang, T.; Tang, G.; Liang, Y.; Wang, W.C.; Yang, J.L.; Niu, J.F.; Tang, J.Y.; Zhou, Z.Y.; Cao, Y.S. Pyrimethanil ionic liquids paired with various natural organic acid anions for reducing its adverse impacts on the environment. J. Agric. Food Chem. 2019, 67, 11018-11024. [CrossRef]

17. Milling, R.J.; Richardson, C.J. Mode of action of the anilino-pyrimidine fungicide pyrimethanil. 2. Effects on enzyme secretion in Botrytis cinerea. Pestic. Sci. 1995, 45, 43-48. [CrossRef]

18. Miao, H.J.; Zhang, J.W.; Yuan, H.Z.; Li, Y.; Xu, Y.; Li, H.; Yang, X.L.; Ling, Y. Synthesis and fungicidal activities of nucleoside compounds containing substituted benzoyl thiourea. Chin. J. Org. Chem. 2012, 32, 915-921. [CrossRef]

19. Sun, J.; Zhou, Y. Design, synthesis and insecticidal activity of some novel diacylhydrazine and acylhydrazone derivatives. Molecules 2015, 20, 5625-5637. [CrossRef]

20. Wang, C.; Song, H.; Liu, W.; Xu, C. Design, synthesis and antifungal activity of novel thioureas containing 1,3,4-thiadiazole and thioether skeleton. Chem. Res. Chin. Univ. 2016, 32, 615-620. [CrossRef]

21. Liu, Y.G.; Luo, Y.; Lu, Y. A concise synthesis of azoxystrobin using a Suzuki cross-coupling reaction. J. Chem. Res. 2015, 39, 586-589. [CrossRef]

22. Liu, Y.; Weng, Y.B.; Chen, Z.B.; Wang, Y.L. Synthesis and anticoccidial activities of quinoline carboxylate derivatives with methyl (E)-2-(3-methoxy) acrylate moiety. Asian. J. Chem. 2013, 25, 8509-8512. [CrossRef]

23. Zhou, Y.L.; Xue, C. Synthesis of pyrimethanil. Pestic. Sci. Admin. 2005, 26, 24-25.

24. Dolomanov, O.V.; Bourhis, L.J.; Gildea, R.J.; Howard, J.A.K.; Puschmann, H. OLEX2: A complete structure solution, refinement and analysis program. J. Appl. Crystallogr. 2009, 42, 339-341. [CrossRef]

25. Sheldrick, G.M. Crystal structure refinement with SHELXL. Acta Crystallogr. Sect. C 2015, 71, 3-8. [CrossRef]

26. Sheldrick, G.M. SHELXT-Integrated space-group and crystal-structure determination. Acta Crystallogr. Sect. A 2015, 71, 3-8. [CrossRef]

27. Li, H.C.; Guan, A.Y.; Huang, G.; Liu, C.L.; Li, Z.N.; Xie, Y.; Lan, J. Design, synthesis and structure-activity relationship of novel diphenylamine derivatives. Bioorg. Med. Chem. 2016, 24, 453-461. [CrossRef]

28. Guan, A.; Liu, C.; Chen, W.; Yang, F.; Xie, Y.; Zhang, J.; Li, Z.; Wang, M. Design, synthesis, and structure-activity relationship of new pyrimidinamine derivatives containing an aryloxy pyridine moiety. J. Agric. Food Chem. 2017, 65, 1272-1280. [CrossRef]

29. Li, Z.Y.; Jia, G.K.; Yuan, L.; Bai, P.F.; He, H.; Zhou, Q. Syntheses, crystal structures and biological activities of three new Schiff bases derived from substituted salicylaldehyde and tris base. Chin. J. Struct. Chem. 2017, 36, 1797-1802.

30. Mahgoub, M.Y.; Elmaghraby, A.M.; Harb, A.E.A.; Mahgoub, M.Y.; Ferreira, D.S.J.L.; Justino, G.C.; Marques, M.M. Synthesis, crystal structure, and biological evaluation of fused thiazolo [3,2-a] pyrimidines as new acetylcholinesterase inhibitors. Molecules 2019, 24, 2306. [CrossRef]

31. Deng, X.L.; Zhou, X.M.; Wang, Z.Y.; Rui, C.H.; Yang, X.L. Synthesis, crystal structure and insecticidal activity of $N$-(pyridin-2-ylmethyl)-1-phenyl-1,4,5,6,7,8-hexahydrocyclohepta[c]pyrazole-3-carbox amide. Chin. J. Struct. Chem. 2018, 37, 551-556.

32. Shi, J.T.; Gong, Y.L.; Li, J.; Wang, Y.; Chen, Y.; Ding, S.; Liu, J. Synthesis, structure and biological activity of 2-[2-(4-fluorobenzylidene)hydrazinyl]-4-(1-methyl-1H-indol-3-yl)thieno[3,2-d]pyrimidine. Chin. J. Struct. Chem. 2019, 38, 1530-1536.

33. Tao, Y.; Han, L.; Sun, A.; Sun, K.; Zhang, Q.; Liu, W.; Du, J.; Liu, Z. Crystal structure and computational study on methyl-3-aminothiophene-2-carboxylate. Crystals 2020, 10, 19. [CrossRef]

34. Manchado, A.; Salgado, M.M.; Vicente, A.; Diez, D.; Sanz, F.; Garrido, N.M. Crystal structure of methyl (4R)-4-(4-meth-oxy-benzo-yl)-4-\{(1R)-1-phenyl-eth-ylcarbamo-yl\}butanoate. Acta Crystallogr. Sect. E 2017, 73, 503-506. [CrossRef]

35. Shen, Z.H.; Shi, Y.X.; Yang, M.Y.; Sun, Z.H.; Weng, J.Q.; Tan, C.X.; Liu, X.H.; Li, B.J.; Zhao, W.G. Synthesis, crystal structure, DFT studies and biological activity of a novel schiff base containing triazolo 4,3-a pyridine moiety. Chin. J. Struct. Chem. 2016, 35, 457-464.

36. Herschlag, D.; Pinney, M.M. Hydrogen bonds: Simple after all? Biochemistry 2018, 57, 3338-3352. [CrossRef]

(C) 2020 by the authors. Licensee MDPI, Basel, Switzerland. This article is an open access article distributed under the terms and conditions of the Creative Commons Attribution (CC BY) license (http://creativecommons.org/licenses/by/4.0/). 